\title{
The Relationship between Teaching Skills, Academic Emotion, Academic Stress and Mindset in University Student Academic Achievement Prediction: A PLS-SEM Approach
}

\author{
Nabi Nazari ${ }^{1, *}$ and Davod Mirzaei Far ${ }^{2, \#}$ \\ ${ }^{1}$ Department of Psychology, Faculty of Human Science, Hamadan Branch, Islamic Azad University, \\ Hamadan, Iran \\ ${ }^{2}$ Faculty of Human Science, Department of Educational Science, University Bu-ALI Sina, Hamadan, Iran
}

\begin{abstract}
This cross-sectional study conducted to develop a model for predicting academic achievement of university students by investigating the relationship between teaching skills, academic emotions (positive and negative), and academic stress associated with Mindset (growth and fixed) using structural equation modeling. The statistical population consisted of 360 students of the Islamic Azad University of Hamedan who were selected randomly using a relative stratified method. The study was descriptive and correlational. The data were analyzed by SPSS version 25 and SmartPLS version 3.2.8. First, the validity of the model was estimated using Cronbach's alpha, composite reliability, convergent validity, and divergent validity; then, the coefficient of determination, effect size, and Stone-Geisser criterion were calculated for evaluating the structural model. The results showed that the validity and adequacy of the suggested model were suitable. Thus, it could be used in different situations by experts in related areas. The relationship between growth Mindset and academic achievement was significant; growth Mindset moderated the effect of negative emotion and stress on academic achievement the crucial role of professor skills in the academic achievement of students was confirmed directly or through its effect on positive emotion. The effect of teaching skills was not significant on the academic achievement of students with fixed Mindset, while the effect of academic stress confirmed on these students. Therefore, the identification of students with fixed Mindset and psychological interventions for these students can be useful in their academic achievement and their mental health.
\end{abstract}

Keywords: Teaching skill, academic emotion, academic stress, mindset, structural equation modeling, Smartpls, higher education.

\section{INTRODUCTION}

Education and promotion of education quality at various academic and professional levels are one of the undeniable factors in the development of countries [1]. Higher education has always been closely associated with the promotion of sustainability and the development of human societies [2]. Universities in the world are already training tens of millions of students to meet the needs of their people and their countries; knowledge-based economics is a priority for advanced countries. Many developing countries have placed higher education at the top of their policies to meet and adapt to social demands [3]. Meanwhile, assessment and prediction of academic achievement as one of the most critical factors in describing the quality of education and the extent to which educational goals are achieved are critical. With the advancement of psychology, the effects of many environmental and cognitive factors have been studied on academic achievement; these studies have led to small and large changes and modifications in details and some

*Address correspondence to this author at the Department of Psychology, Faculty of Human Science, Hamadan Branch. Islamic Azad University, Hamadan, Iran; Tel: 08134481000; Fax: 08134494059;

E-mail: nazariirani@gmail.com

\#Co-author E-mail: davod.mirzai@yahoo.com cases, even in educational organizations in different countries. The importance of academic achievement, in addition to its effect on national macroeconomic and educational policies, is evident, as academic achievement of students is one of the determinant factors in the assessment of educational quality [4].

\subsection{Teaching Skill}

In its report on analysis of workforce skill and innovation in 2011, the Organization for Economy and Development (OECD) points out skill as a challenging concept, which involves skill as merely a combination of formal education, informal learning, and experience due to a disagreement of theorists in achieving a single definition. Like skill, the definition of teaching is a challenging topic among experts in the field of education. Some argue that viewpoint of different scholars about the definition of teaching is not focused on the search for a single definition; rather than a theoretical discussion of teaching and its related subjects, one can speak of a variety of useful teaching [5]. The role of teachers as the main actors is evident in the field of education and reformation and the promotion of the quality of education [6]. The educational assessment has been the focus of many educational studies, in Spanish universities, which has probably attracted the most attention [7]. Almost all 
academic institutions in Spain have set up a new evaluation system to assess the quality of professors' activities, the purpose of which is to implement a kind of teaching and training that accomplishes the following objectives [7, 8]:

A. Training of professional, social and cultural requirements in different branches

B. Knowledge Governance in the field of education

C. Development of practical and applied knowledge

D. Problem-solving skills, teamwork, ethical orientation in professional work

E. Encouragement of students to self-control and self-efficacy in learning to institutionalize lifelong learning in students

F. Application of information and communication technology and Web facilities, such as scientific databases, online education, and empowerment of students to use them effectively.

Hanushek et al. [9] investigated the relationship between teacher quality and student achievement.

They explained that the teacher cognitive skill is a significant, and a powerful determinant of the international gap in student performances. The importance of well-trained and skilled teachers, especially in the context of urban high poverty education settings, becomes even more salient [10]. Unfortunately, many professional development activities were ineffective in supporting changes in teachers' practices and student outcomes.

\subsection{Academic Emotion}

Academic emotion is one of the topics which has been considered in the last decade. Educational researchers have examined emotions in educational settings. Researchers believe that education is full of emotions process [11] and emotions play an essential role in the education, learning, and social communication of students [12]. Emotions are always present in academic and clinical environments. These emotions are most likely to influence readiness, motivation to cope with problems and efforts of students and even their strategies for apprehension.

Emotions that directly relate to educational activities or outcomes are defined as academic emotions [12], motivation to cope with problems and efforts of students, and even their strategies for apprehension [13].

Emotions that directly relate to educational activities or outcomes are defined as academic emotions [12]. Students experience a wide range of positive and negative emotions during their studies, including enjoyment, hope, anxiety, shame, and anger

In this context, some scholars consider emotions as important factors that explain motivation and academic success. The results of the studies show that emotions have a significant effect on education and academic learning and, in other words, facilitate or prevent education. In other words, academic emotions associated with consequences related to the advancement of academic goals, goal orientation [12], academic achievement [12], self-regulation and selfdirected learning [13], and perceived behavior control [11]. Through a study, Pekrun [12] concluded that there is a significant relationship between positive emotions such as enjoyment and hope and midterm exam scores of the students. On the other hand, negative emotions such as anger, anxiety, shame, hopelessness, and frustration were negatively related to midterm scores of students. One of the skills needed for the future generation of teachers is the ability to teach how to recognize and control emotions. One of the skills required for future generations of teachers is the ability to recognize academic emotions during teaching and how to control those [15].

\subsection{Academic Stress}

One student commits suicide per hour [16]. The most important cause of this disastrous situation is academic stress [17]. Academic stress refers to the sense of the need for knowledge and one's simultaneous perception that there is not enough time to acquire knowledge. Pathological factors of these stresses may include the inability to manage time, the lack of academic skills of competing with classmates [18].

Students manifest a series of physical and psychological responses to stressors [19]. Stress manifestations include physical injuries, chronic energy shortages, motivational poverty, headache, digestive problems, and sleep problems or disorders [20]. Academic stress usually brings poor academic performance $[20,21]$. 


\subsection{Mindset}

One of the successes of psychology is the development of intelligence tests. Intelligence tests represent predictive phenomena and are one of the highly valid instruments are widely used in various fields, particularly in educational areas [22, 23]. According to the findings of neurologists, the scores obtained in intelligence tests are related to functional characteristics of the brain [23-25]. Despite advertisements about increasing intelligence through cognitive interventions or mental exercises [24], these claims are unfounded and myth.

Psychologists and specialists in education have studied this from another perspective. The implicit belief of people about the incremental or entity nature of intelligence plays a fundamental role in the academic achievement of people [26-28]. The effect of these beliefs is exhibited in stressful situations and educational challenges [29]. Do intelligence and talent are fixed and unchangeable features or can effort expand them?

According to Dweck [30], the answer that people give to this question reflects their kind of Mindset. Based on this, Dwek defines two types of mindset: a) growth; b) fixed.

The Mindset of people affects their way of confronting problems and challenges. People with growth Mindset will probably struggle despite these obstacles. Those students who believe that mental abilities are developable features can achieve higher levels of education during study and overcome more challenging problems. These people believe that they can overcome problems by working more and using more effective strategies. In a fixed mindset, people believe that their intrinsic qualities, such as intelligence or talent, are just fixed features and only talent without effort leads to success. The effect of mindset on academic achievement has been confirmed by many studies. People with growth mindset tend to be diligent and persevering; their goals of learning are for personal growth and personalization; they have effort skill strategies to overcome higher educational disadvantages and they believe that achievements can be made by effort. Recent studies indicate that these beliefs have a significant effect on academic achievement [29, 31, 32]. In the area of Mindset research, the focus has been on the period before the university and there is a gap in the field of Mindset research on university students.

\subsection{Academic Achievement}

Academic achievement is one of the most important criteria which plays a significant role in examining the ability of students to complete university education and graduate. Bussato, Prins, Elshout, and Hamaker [33] argue that an explanation of academic achievement has been one of the pivotal issues for educational psychologists. A set of individual and environmental factors or cognitive and non-cognitive factors affects academic achievement. Expanding research and findings at higher education level rejects any simplistic thinking to explain academic achievement. Academic achievement can be measured in a variety of ways, including the extent to which progress is made in each of the courses individually, the progress achieved in the training courses, annual GPA, GPA in an educational program. Due to its personal and social consequences, educational progress is one of the essential educational constructs which are essential in the education of students.

\subsection{Objective}

This study tended to develop a model for predicting the academic achievement of university students by examining the relationship between teaching skill, academic emotion (positive and negative), academic stress and mindset (fixed and growth) by using the structural equation modeling PLS approach and hypothesized that. (1) Teaching skills will be associated with growth and fixed mindset, academic emotion, academic stress 2) The interactive effects of teaching skills, academic emotions, stress, and mindset predict academic achievement in university students.

3) A growth mindset and a fixed mindset have a significant effect on academic achievement. 4) The mindset (growth and fixed) would moderate the relationship between other variables with academic achievement.

\section{MATERIALS AND METHODS}

This study was a cross-sectional descriptive correlation study which was carried out using structural equation modeling. The statistical population consisted of students of Islamic Azad University, Hamedan Branch. An essential question in factor analysis is to determine the minimum sample size $[34,35]$. According to many scholars, a minimum sample size of 200 can 


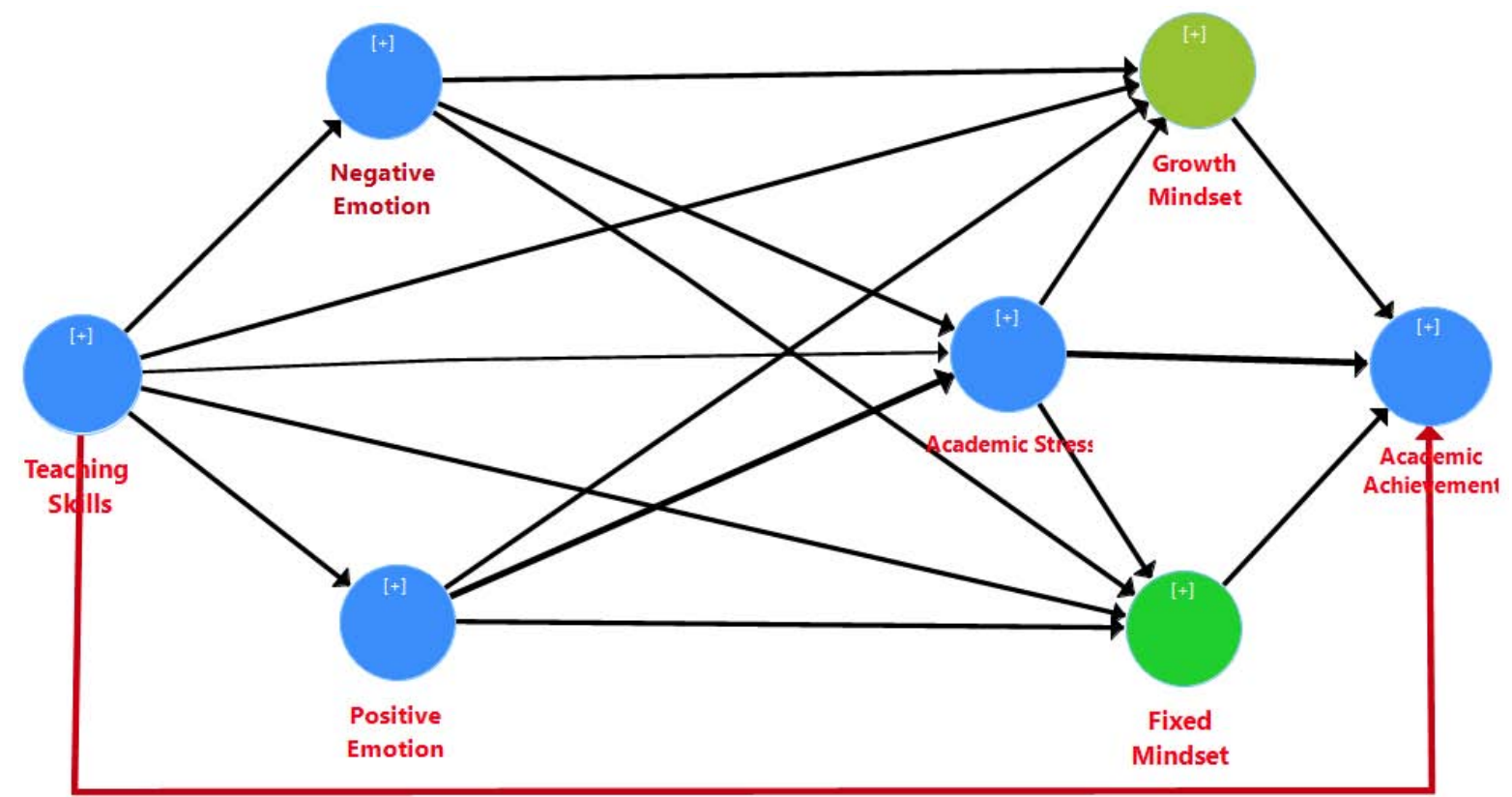

Figure 1: The suggested model of relationship between teaching skills, academic emotions (positive and negative), academic stress and mindset (growth and fixed) in predicting academic achievement.

be reasonable [34]. One of the methods used to determine sample size in PLS-based models is to use the "10-time" method [36, 37]. The minimum sample size should be ten times the highest input and output paths to the latent variable, which has the highest index in the measurement model. Finally, the sample size of the present study was 350 , which were selected randomly by the relative stratified method in three stages.

\subsection{Instruments}

\subsubsection{Teaching Skills}

The instrument used to measure the teaching skills of the professors was developed by Camara, Lopez, and Huertas [38]. Cronbach's alpha was reported for teaching method $(\alpha=0.92)$, lesson guide $(\alpha=0.90)$, beliefs and attitudes $(\alpha=0.93)$, resources $(\alpha=0.91)$, and evaluation $(\alpha=0.89)$ and for the whole questionnaire $(\alpha=0.91)$. The scores for this scale range from "strongly disagree" (1) to "strongly agree" (5). The instrument consists of 40 items and five reliable factors: teaching methodology $(\alpha=0.93)$, design of the course guide (theory and practice) $(\alpha=$ $0.90)$, teachers' attitude $(\alpha=0.91)$, internal coherence of teaching resources $(\alpha=0.83)$, and information on evaluation systems $(\alpha=0.76)$; A unique point of the study by Camara et al. (2015) is that the suggested model is based on the needs of students and their attitudes about the skills of professors. While many assessment models based on policies of institutions or administrations of higher education.

\subsubsection{Academic Emotions}

The questionnaire developed by Pekrun et al. [39] was used to calculate academic emotions. Among academic emotions. The AEQ has three sections, but only the Class-Related Emotion Scales were used in our study. The items related to enjoyment and pride were selected to measure positive emotion and the factors related to anxiety, shame, and anger were selected to measure negative emotions.

\subsubsection{Academic Stress}

Academic stress assessed by García-Ros, PérezGonzález \& Tomás [40]. The questionnaire measured academic stress in four different dimensions. We extracted items related to academic overload and interaction with classmates. These items are linkage with sources of academic stress those experienced in an educational environment. The initial version of the ASQ used in the study comprised 30 items related to different potentially stress-producing situations in education, Students' responses reveal their stress level in the different school situations on a Likert-type scale with five response options ( 1 = "Very low," to $5=$ "Very high").

\subsubsection{Mindset}

Online Carol Dweck's Mindset instrument scale Adapted by Corey, Corey, \& Muratori [41] used. It consists of 16 items and two subscales: growth Mindset and fixed Mindset. Growth Mindset included (4 
items) that measures intelligence and (4 items) measures talent. Fixed Mindset included (4 items) that measures intelligence and (4 items) measures talent. Sample items include: "I do not think I personally can do much to increase my intelligence" (Entity Self Beliefs) and "With enough time and effort I think I could significantly improve my intelligence level" (Incremental Beliefs).

Youth respond on a 6-point scale: Strongly disagree, Disagree, Mostly disagree, mostly agree, Agree, or strongly agree.

\subsubsection{Academic Achievement}

The overall GPA considered in this study. The GPA obtained from the head of the department of education in each faculty by providing permission and student number.

\subsection{Methods}

This study was a cross-sectional study conducted using a Representative Sample. According to official reports, 25000 students were studying between 2017 and 2018 in 3 grades. About 16, 000(64\%) undergraduate students, $8000(33 \%)$ students in a master's degree, and 200(1\%) doctoral students were studying at Hamedan IAU. Accordingly, in the first step, the subjects were randomly selected according to educational grade and gender using a relative stratified method. All teachers agreed to participate in this study, and they provided enough time for students to complete questionnaires. In the next stage, 360 questionnaires distributed. The subjects assured that none of their responses would influence their course grade and briefed about confidentiality and study objectives. GPA self-reported by students and used as a criterion for honesty and verification. In examining and inserting the data, self-reported GPA did not match in 10 questionnaires with information obtained from the Head of Education.

Also, they deleted. Data from 8 participants with missing value, removed too. Finally, 342 questionnaires with no outlier were approved. The data were computerized by SPSS version 25 ; structural equation modeling was used to test the model. SmartPLS version 3.2.8 (the latest versions available) used. The first step in evaluating PLS-SEM results involves examining the measurement models.

\section{RESULTS}

There were no missing values in the assessed variables, and no imputation method implemented. Three hundred sixty questionnaires distributed and 18 questionnaires removed after data collection. The number of data confirmed was 342 . In the study of the demographic characteristics of the participants, 182 of the male students (58.2 percent) and 160 female students (47.8 percent) contributed to this study. The number of 204 students at a bachelor's degree (62\%),

Table 1: The Results of Model Measurement (Convergent Validity)

\begin{tabular}{|c|c|c|c|c|c|}
\hline C.R & Ave & $\alpha$ Cronbach & Vif & Factors & Construct \\
\hline \multirow[t]{5}{*}{0.905} & \multirow[t]{5}{*}{0.655} & \multirow[t]{5}{*}{0.868} & 2.055 & Attitude & \multirow[t]{5}{*}{ Teaching Skill } \\
\hline & & & 2.451 & Evaluation & \\
\hline & & & 1.807 & Lesson Guide & \\
\hline & & & 1.825 & Teaching Method & \\
\hline & & & 2.075 & Resources & \\
\hline \multirow[t]{2}{*}{0.913} & \multirow[t]{2}{*}{0.84} & \multirow[t]{2}{*}{0.81} & 1.866 & Enjoyment & \multirow[t]{2}{*}{ Positive Emotion } \\
\hline & & & 1.8 & Pride & \\
\hline \multirow[t]{3}{*}{0.84} & \multirow[t]{3}{*}{0.639} & \multirow[t]{3}{*}{0.716} & 1.462 & Anger & \multirow[t]{3}{*}{ Negative Emotion } \\
\hline & & & 1.674 & Anxiety & \\
\hline & & & 1.306 & Shame & \\
\hline \multirow[t]{2}{*}{0.876} & \multirow[t]{2}{*}{0.78} & \multirow[t]{2}{*}{0.718} & 1.457 & Academic Overload & \multirow[t]{2}{*}{ Academic Stress } \\
\hline & & & 1.557 & Interaction With Classmates & \\
\hline \multirow[t]{2}{*}{0.95} & \multirow[t]{2}{*}{0.905} & \multirow[t]{2}{*}{0.895} & 1.856 & Intelligence & \multirow[t]{2}{*}{ Growth Mindset } \\
\hline & & & 1.9 & Talent & \\
\hline \multirow[t]{2}{*}{0.913} & \multirow[t]{2}{*}{0.839} & \multirow[t]{2}{*}{0.809} & 2.905 & Intelligence & \multirow[t]{2}{*}{ Fixed Mindset } \\
\hline & & & 2.91 & Talent & \\
\hline 1 & 1 & 1 & 2.451 & Gpa & ACADEMIC ACHIEVEMENT \\
\hline
\end{tabular}


125 people were educated at a master's degree (36 \%) and $13(1.5 \%)$ at the Ph.D. level.

\subsection{Measurement Model Evaluation}

To validate the measurement model in PLS, convergent validity, and divergent validity were used.

\subsubsection{Convergent Validity}

According to Gefen and Straub [42], convergent validity shows a significant correlation between a construct so its indices. For this purpose, composite reliability and average variance extracted (AVE) used. The validity and reliability of the constructs and goodness of the instruments were also evaluated using Cronbach's alpha. The third criterion of convergent validity is the factor load value of the observed variable with its latent variable.

\subsubsection{Variance Inflation Factor}

One of the crucial assumptions in structural equation modeling is the lack of collinearity between independent variables. None of the independent variables should have a linear relationship with each other. A co-linear relationship indicates that an independent variable is a linear function of other independent variables. If collinearity is high, it means that there is a high correlation between independent variables; thus, the model is not highly valid despite the high coefficient of determination (Table 1).

\subsubsection{Divergent Validity}

Divergent validity is the third criterion for fitting the measurement models in PLS. Divergent validity measures the degree of correlation of questions and factors of a latent variable with other uncorrelated latent variables. Hetrotrait-Monotrait coefficients were used to examine divergent validity [42]. The HTMT values which are $<0.85$ indicate divergent validity in the model [43]. According to Tables $1 \& 2$, the reported convergent and divergent validity were suitable.

\subsection{Structural Model}

For the final results computations and assessments, using a large number $(5,000)$ of bootstrap subsamples. Bias-Corrected and Accelerated Bootstrap procedure applied in two tale type with 0/05 significance level.

\subsubsection{Coefficient of Determination, Stone-Giesser Factor and Effect Size}

The coefficient of determination, $\mathrm{R}^{2}$ (squared coefficient of correlation) is a measure that represents the extent of variation in each of the dependent variables of the model and is explained by independent variables. The $R^{2}$ value is presented only for endogenous variables of the model, and it is equal to zero for exogenous constructs. The higher the $\mathrm{R}^{2}$ value of the endogenous constructs of the model, the better the fit of the model. Chen [45] introduced three values of $0.19,0.33$, and 0.67 as a weak, medium, and robust values for fitting the model. The next criterion for examining the structural model in $Q^{2}$. This criterion, which was suggested by Stone [47] and Geisser [48], determines the prediction ability of the model independent variables. They believe that models of which the structural part is acceptably fitted should have the ability to predict indices related to endogenous constructs of the model. This means that if the relationships between constructs of a model are appropriately defined, the constructs will be able to have an adequate effect on indices of each other, and thus the hypotheses are correctly confirmed. The results show the adequate ability of the constructs in the predictive power of indicators. Table 3 reports $R^{2}$ and $R^{2}$ adjusted and $Q^{2}$ values.

Figure 2 included an effect size coefficient. According to Cohen [49] $f^{2}$ values above $0.35,0.15$, and 0.02 can be regarded as reliable, moderate, and weak, respectively. All paths whose effect size less than 0.15 deleted. The final model, including paths

Table 2: HTMT (Hetrotrait-Monotrait) Values

\begin{tabular}{|c|c|c|c|c|c|c|}
\hline Variable & $\begin{array}{c}\text { Academic } \\
\text { achievement }\end{array}$ & $\begin{array}{c}\text { Academic } \\
\text { stress }\end{array}$ & Fixed Mindset & $\begin{array}{c}\text { Growth } \\
\text { Mindset }\end{array}$ & $\begin{array}{c}\text { Negative } \\
\text { emotion }\end{array}$ & $\begin{array}{c}\text { Positive } \\
\text { emotion }\end{array}$ \\
\hline \hline Academic stress & 0.503 & & & & \\
\hline Fixed mindset & 0.646 & 0.572 & & & \\
\hline Growth mindset & 0.632 & 0.625 & 0.604 & 0.687 & 0.544 & \\
\hline Negative emotion & 0.544 & 0.662 & 0.511 & 0.507 & 0.764 & 0.433 \\
\hline Positive emotion & 0.609 & 0.715 & 0.776 & 0.663 & 0.817 & 0.661 \\
\hline Teaching skills & 0.715 & & 0.711 \\
\hline
\end{tabular}


Table 3: $\mathbf{R}^{2}$ and $\mathbf{R}^{2}$ Adjusted and $\mathbf{Q}^{2}$ Values

\begin{tabular}{|c|c|c|c|}
\hline & R Square & R Square Adjusted & Q $^{2}$ \\
\hline \hline Academic Achievement & 0.764 & 0.762 & 0.622 \\
\hline Academic Stress & 0.742 & 0.74 & 0.661 \\
\hline Fixed Mindset & 0.716 & 0.715 & 0.74 \\
\hline Growth Mindset & 0.742 & 0.513 & 0.625 \\
\hline Negative Emotion & 0.515 & 0.477 & 0.511 \\
\hline
\end{tabular}

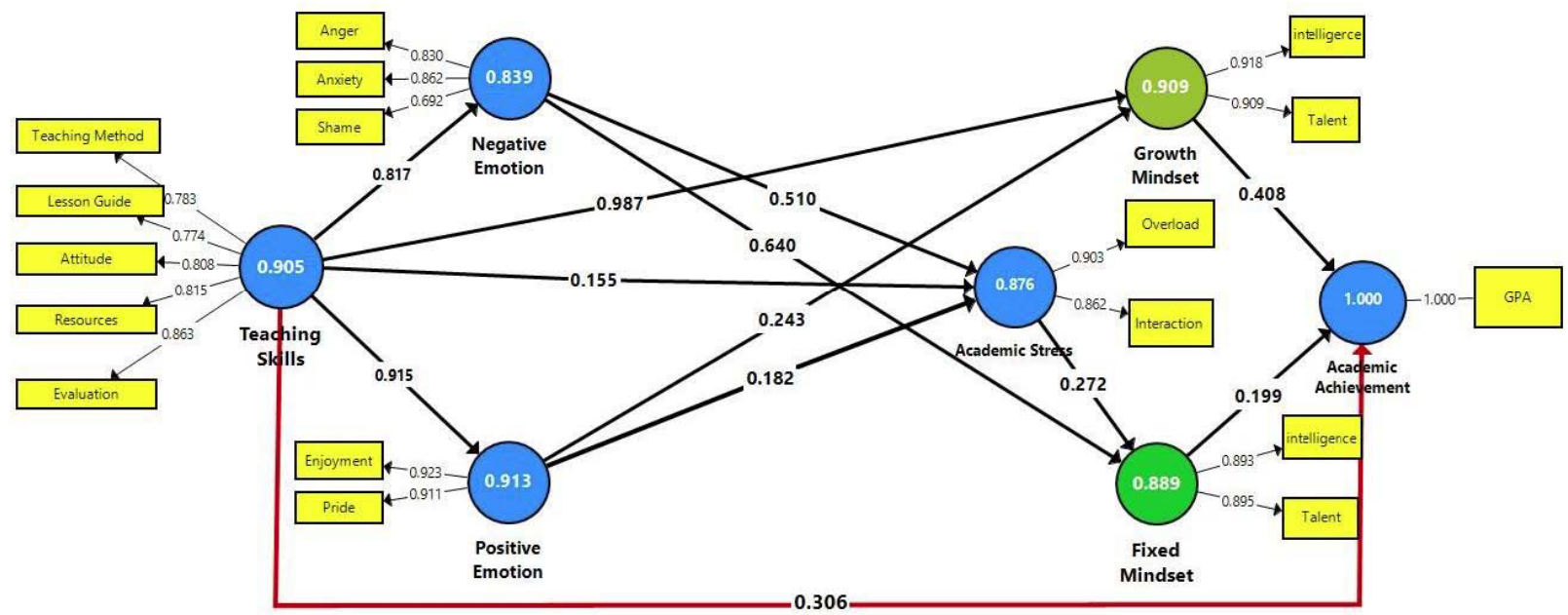

Figure 2: Effect size (C.R value in circle).

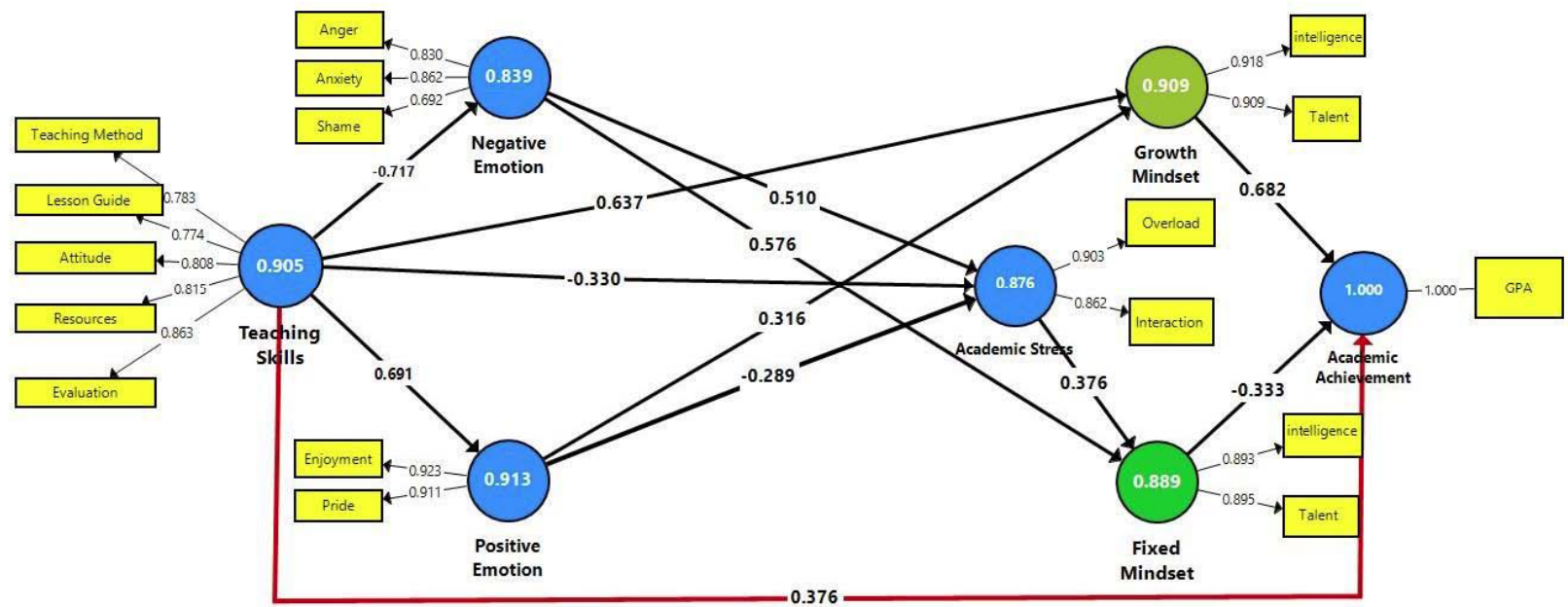

Figure 3: Final model (path coefficients).

whose effect size was significant, was confirmed according to Figure 3 for all the criteria considered.

\subsection{Fitting the Model in SmartPLS}

A value less than 0.10 or of 0.08 (in a more conservative version) is considered a good fit. Henseler et al. [44] introduce the SRMR as a goodness of fit measure for PLS-SEM that can be used to avoid model misspecification. SRMR $<0.08$ [44] shows an acceptable fit of the model, and SRMR $<0.05$ indicates the optimal fit of the model. In this study, SRMR=0.045. 
Table 4: Moderator Effect of Mindset (Growth, Fixed)

\begin{tabular}{|c|c|c|c|c|}
\hline Independent Variable & Moderator Variable & Dependent Variable & T Statistics & P Value \\
\hline Teaching Skills & Fixed Mindset & Academic Achievement & 5.926 & 0.001 \\
\hline Positive Emotion & Fixed Mindset & Academic Achievement & 7.161 & 0.001 \\
\hline Academic Stress & Growth Mindset & Academic Achievement & 7.151 & 0.001 \\
\hline Negative Emotion & Growth Mindset & Academic Achievement & 6.354 & 0.001 \\
\hline
\end{tabular}

Table 5: The Specific Indirect Effects

\begin{tabular}{|c|c|c|}
\hline Specific Indirect Effects & T-Statistics & P-Value \\
\hline Academic Stress $\rightarrow$ Growth Mindset $\rightarrow$ Academic Achievement & 2.995 & 0.01 \\
\hline Teaching Skills $\rightarrow$ Academic Stress $\rightarrow$ Fixed Mindset $\rightarrow$ Academic Achievement & 2.815 & 0.01 \\
\hline Negative Emotion $\rightarrow$ Growth Mindset $\rightarrow$ Academic Achievement & 3.11 & 0.01 \\
\hline Teaching Skills $\rightarrow$ Negative Emotions $\rightarrow$ Fixed Mindset $\rightarrow$ Academic Achievement & 3.075 & 0.01 \\
\hline Teaching Skills $\rightarrow$ Academic Stress $\rightarrow$ Fixed Mindset $\rightarrow$ Academic Achievement & 2.815 & 0.01 \\
\hline Teaching Skills $\rightarrow$ Fixed Mindset $\rightarrow$ Academic Achievement & 3.98 & 0.001 \\
\hline Negative Emotion $\rightarrow$ Growth Mindset $\rightarrow$ Academic Stress & 9.16 & 0.001 \\
\hline Teaching Skills $\rightarrow$ Negative Emotion $\rightarrow$ Academic Stress $\rightarrow$ Fixed Mindset & 8.856 & 0.001 \\
\hline Positive Emotion $\rightarrow$ Academic Stress $\rightarrow$ Fixed Mindset & 3.902 & 0.001 \\
\hline
\end{tabular}

To test the moderating influence of Mindset (growth and fixed), we followed a mediation analyze in smart pls. We, individually, applied a bias-corrected bootstrapping is considered a powerful method to detect mediation [50]. A statistically significant indirect effect, listed as Table 4, (t-value > 1.96, two-tailed, $p<$ 0.05 ) should be taken as an evidence for mediation.

\section{DISCUSSION AND CONCLUSION}

This study tended to investigate the relationship between the teaching skills of professors, academic emotions of students, academic stress and mindset, and their contribution to predicting academic achievement in higher education with designed four hypothesizes. To the best of our knowledge, this study marks the first Smartpls model that has been suggested to include all of these variables in higher education. Indices related to the measurement model and structural model were suitable, which indicates the validity and reliability of the instruments and the final model hypothesis $(1 \& 2)$ - the strong effect of teaching skills on academic emotions. The effect of teaching skills and positive emotions on students with a negative mindset was not confirmed. Meanwhile, the effect of teaching skills and positive emotions was considerably significant on students with a growth mindset. Given these findings, psychological and counseling interventions can consider as an essential requirement for those students with a negative mindset.

In analyzing relationships between variables through the moderating effect of growth and fixed mindset (hypothesis 3 ) on academic achievement, the moderating effects of a fixed mindset on relationship between teaching skills and positive emotion on academic achievement were significant. It can highlight the importance of a fixed mindset on academic failure and urgent needing counseling intervention in a fixed mindset to success in academic assignments.

Moderator influences the growth mindset in the relationship between academic stress and negative emotion on academic achievement was confirmed. It is consistent with Aditomo [51]. Aditomo examined the effect of emotions on academic achievement through the growth mindset and revealed the critical role of the growth mindset as a buffer against negative emotions. On the other hand, negative emotions were highly effective on a fixed mindset; simultaneously, a significant relationship reported with academic stress Growth mindset thoughts can be applied as a coping strategy to relief academic stress and well-being. Resilience and academic tenacity of students with growth are higher in confronting challenges. 
The mindset can predict achievements. Claro and Loeb [52] confirmed the effect of growth Mindset in prediction academic achievement on Students with different nationalities and cultures showed that academic engagement and activities related to learning could be observed throughout the year in students with a growth mindset, disregarding cultural and social contexts. They found that students who were successful in English literature and Math had beliefs related to a growth mindset.

The teaching skill effect had significant on academic stress. Bahadır-Yılmaz [53] revealed that being criticized by teachers is the highest frequencies stressors in nursing academic and clinical settings, and fear of failure is another everyday stressors. He believed that instructors are responsible for these stressful situations and suggested a mentoring programme as a helpful strategy to reduce stress and helps students cope with unpleasant issues.

A recent study [54] claims that Mindset can reduce the effect of poverty on student achievement with low socioeconomic background. As previous stated, skillful teachers also have the same positive effect.

The relationship between positive emotions and growth Mindset and negative emotions and fixed Mindset were respectively significant. it was in consistent [55] findings that indicated fixed, compared to growth, emotion beliefs would produce less effort invested in emotion regulation. Academic stress predicted fixed Mindset.

According to Beck [56], the wrong beliefs of people about their abilities can lead to emotional disorders and pathological outcomes. Accordingly, students with a fixed mindset need special attention and psychological interventions, in some cases, to cope with stressful situations quickly and overcome their shortcomings by additional effort. Professors, teachers, especially new teachers, can largely contribute to success and academic achievement of students by awareness about academic emotions and using cognitive approaches in teaching method and education. They can provide an enjoyable experience of learning by providing correct feedbacks and supporting the students. Growth Mindset beliefs can blend in the curriculum of students in earlier education, and teachers must be informed about mindset influences.

These characteristics and well organized interactions between teachers and students are
Associated with positive academic student achievements. Ruzek et al. [57] indicated the role of Emotionally-supportive classroom atmosphere in learning experienced by students. Students reported they had had more developmentally-appropriate opportunities to exercise.

Warmth reflects teachers' facilitation of a classroom environment in which positive and respectful interactions occur regularly [58]. Within a warm classroom environment, students feel more comfortable expressing themselves and taking academic risks [59].

Teachers' skill at fostering warm and emotionally supportive classrooms and pedagogical strategy is crucial to high-quality instruction [60] and has been found to predict increased student motivation and academic engagement $[57,58]$.

Pekrun [61] explains the relationship between taskrelated positive emotions and learning. Enjoyment can promote students' flow experiences during learning, such as deep involvement and complete immersion in the activity. Positive academic emotions play different rules in comparison with other emotions. Positive emotions influence learning by affecting students' attention, motivation, use of learning strategies, and self-regulation of learning. On the other hand, the excitement increases physiological parameters of arousal, and it follows that student attention is distracted away from current task performance. As a high key in Pekrun [61] report, positive emotions that do not relate to learning can draw attention away and lower performance, such as a Student falling in love reducing his/her academic effort. Similarly, deactivating positive emotions, such as relief and relaxation, do not necessarily have positive effects. So, teachers can recognize distracting positive emotion from positive academic emotion through systematic qualitative and quantitative evaluations. Professors, teachers, especially, new teachers, can largely contribute to learning by providing corrective feedback and supporting the students.

The Growth Mindset beliefs can blend in the curriculum of students in earlier education, and teachers must be informed about mindset influences. Success and academic achievement of students by awareness about academic emotions and using cognitive approaches in teaching methods and education. They can provide an enjoyable experience of the learning. 
Life-long learning is not only limited in our field and development of professional skills, especially when we talk about professors. Attention to new and scientific psychological findings in education areas and unbiased acceptance beliefs about findings and similar efforts across professors can be a start point for compensation of achievement students' gap.

\section{ABBREVIATION}

lauh = Islamic Azad University Hamedan

\section{APPENDIX 1}

DOMAIN: Academics OUTCOME: Mindset for Intelligence and talent
Asq $=$ Academic Stress Questionnaire
Aeq = Academic Emotion Questionnaire
Vif $=$ Variance Inflation Factor
Pls = Partial Least Equation
SEM = Structural Equation Modeling
Ave $=$ Average Variance Extracted

MEASURE: Revised Implicit Theories of Intelligence and talent (Self-Theory) Scale.

The following questions are exploring students' beliefs about their personal ability to change their intelligence and talent level. There are no right or wrong answers. We are just interested in your views. Using the scale below, please indicate the extent to which you agree or disagree with the following statements.

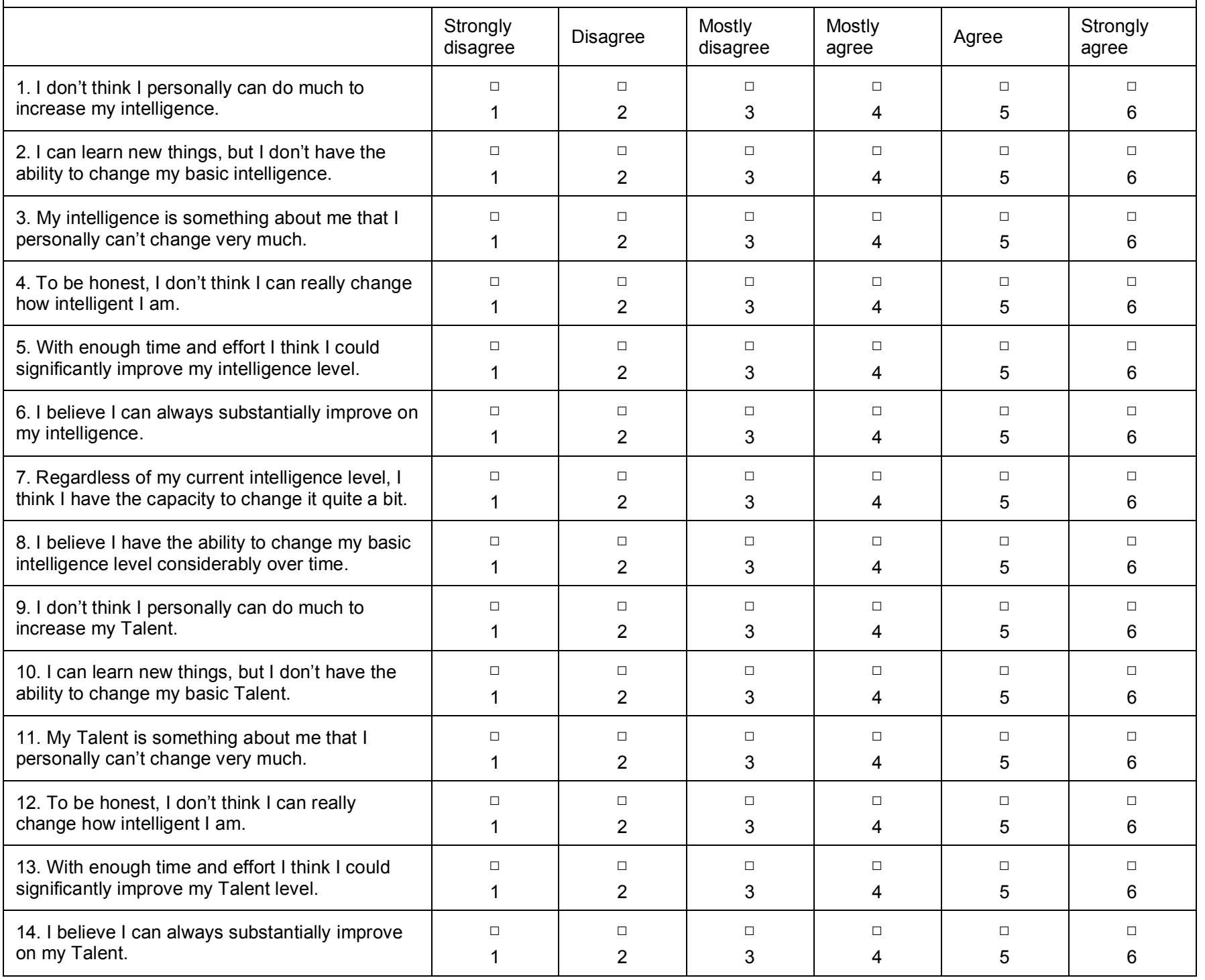




\begin{tabular}{|l|c|c|c|c|c|}
\hline $\begin{array}{l}\text { 15. Regardless of my current Talent level, I think } \\
\text { I have the capacity to change it quite a bit. }\end{array}$ & $\begin{array}{l}\square \\
1\end{array}$ & 2 & $\square$ & $\square$ \\
\hline $\begin{array}{l}\text { 16. I believe I have the ability to change my } \\
\text { basic Talent level considerably over time. }\end{array}$ & $\square$ & $\square$ & $\square$ & $\square$ & 5 \\
\hline
\end{tabular}

\section{APPENDIX 2. ACADEMIC ACHIEVEMENT}

The following questions pertain to feelings you may experience. Please indicate how you feel, typically, before you go to class.

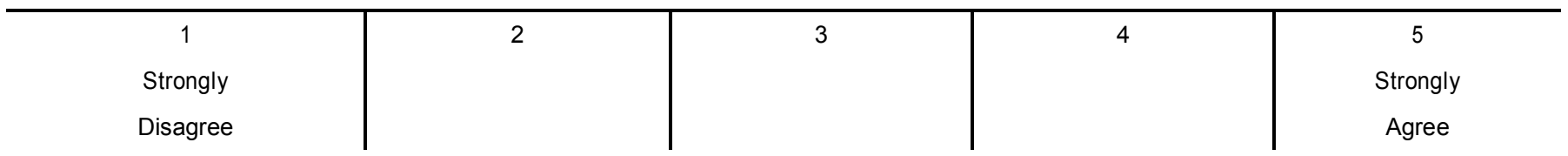

The following questions pertain to feelings you may experience DURING class. Please indicate how you feel, Typically, during class.

\section{During Class}

1. I get excited about going to class.

2. It's pointless to prepare for class since I don't understand the material anyway.

3. Even before class, I worry whether I will be able to understand the material.

4. Being confident that I will understand the material motivates me.

5. I am looking forward to learning a lot in this class.

6. Because I'm so nervous I would rather skip the class.

7. I am confident when I go to class.

8. I wish I didn't have to attend class because it makes me angry.

9. I am full of hope.

10. Even before class, I am resigned to the fact that I won't understand the material.

11. I am motivated to go to this class because it's exciting.

12. I worry whether I'm sufficiently prepared for the lesson.

13. My confidence motivates me to prepare for class.

14. The thought of this class makes me feel hopeless.

15. I worry whether the demands might be too great.

16. My hopes that I will be successful motivate me to invest a lot of effort

17. Thinking about class makes me feel uneasy.

18. Because I've given up, I don't have energy to go to class.

19. When I think about class, I get queasy.

20. I am optimistic that I will be able to keep up with the material.

21. I feel scared.

22. I'd rather not go to class since there is no hope of understanding the material anyway.

23. I am hopeful that I will make good contributions in class.

24. I enjoy being in class.

25. I worry the others will understand more than me.

26. I'm tempted to walk out of the lecture because it is so boring.

27. When I say something in class I feel like I turn red.

28. I feel frustrated in class.

29. Because the time drags I frequently look at my watch.

30. I take pride in being able to keep up with the material.

31. Because I don't understand the material I look disconnected and resigned.

32. My enjoyment of this class makes me want to participate.

33. I get restless because I can't wait for the class to end. I think about what else I might be doing rather than sitting in this boring class.

34. After class I start looking forward to the next class.

35. I am ashamed because others understood more of the lecture than I did.

36. I wish I could tell the teachers off.

37. I am proud of myself.

38. I am happy that I understood the material.

39. I'd rather not tell anyone when I don't understand something in class.

40. I am angry.
41. I think that I can be proud of what I know about this subject.

42. I feel so hopeless all my energy is depleted.

43. I am glad that it paid off to go to class.

44. Because I take pride in my accomplishments in this course, I am motivated to continue.

45. When I think of the time I waste in class I get aggravated.

46. I feel hopeless continuing in this program of studies.

47. I would like to tell my friends about how well I did in this course.

48. I feel hopeless.

49. When I say anything in class I feel like I am making a fool of myself.

50. I get tense in class.

51. I get bored.

52. I am confident because I understand the material.

53. After I have said something in class I wish I could crawl into a hole and hide.

54. I feel anger welling up in me.

55. I am proud that I do better than the others in this course.

56. It's so exciting that I could sit in class for hours listening to the professor.

57. I get so bored I have problems staying alert.

58. I get embarrassed.

59. Thinking about the poor quality of the course makes me angry.

60. I start yawning in class because I'm so bored.

61. When I make good contributions in class, I get even more motivated.

62. I'm embarrassed that I can't express myself well.

63. I feel hopeless.

64. I enjoy participating so much that I get energized.

65. I feel nervous in class.

66. The lecture bores me.

67. Because I get embarrassed, I become tense and inhibited.

68. I am proud of the contributions I have made in class.

69. Because I'm angry I get restless in class.

70. I have lost all hope in understanding this class.

71. I get scared that I might say something wrong, so I'd rather not say anything.

72. During class I feel like I could sink into my chair.

73. I am ashamed.

74. Thinking about all the useless things I have to learn makes I irritated.

75. When I do well in class, my heart throbs with pride.

76. Because I get bored my mind begins to wander.

77. When I talk in class I start stuttering.

78. I find this class fairly dull.

79. If the others knew that I don't understand the material I would be embarrassed.

80. When I don't understand something important in class, my heart races. 


\section{APPENDIX 3. STRESS QUESTIONNAIRE}

1. Taking exams

2. Presentations of work in class

3. Intervening in class (e.g., asking questions, participating in debates)

4. Dealing with the teacher outside of class (e.g., in homeroom, office visits)

5. Academic overload (having too many exams and tasks to do)

6. Lack of time to fulfill all the activities we are asked to do

7. Competitiveness among classmates

8. Doing tasks that involve looking for information and writing

9. The task of studying (e.g., meeting established schedules, level of effort)

10. Working with classmates on tasks in class

11. Problems or conflicts with teachers

12. Problems or conflicts with classmates

13. Being able to attend all the classes

14. Too much responsibility to fulfill my obligations

15. Obtaining high grades in different subjects

16. Future academic and professional perspectives

17. Choosing subjects in the coming courses

18. Getting or keeping a grant to study

19. Finishing 10 th grade in the stipulated time periods

20. Family pressure to obtain good grades

21. Lack of support from my teachers

22. Keeping up with the academic activities and tasks

23. My relationships with my classmates

24. Doing things well in all the subjects in the course

25 . Family discussions and conflicts caused by my studies

26. Making leisure time and academic work compatible

27. Teachers' pressure about my work and behavior

28. The fact that my parents are always on top of me

29. Doing poorly on an exam.

30. The fact that my classmates think I'm not a good student

\section{APPENDIX/4: TEACHING SKILL QUESTIONNAIRE:}

\begin{tabular}{|c|c|c|c|c|c|c|c|}
\hline 1 & 2 & 3 & \multicolumn{2}{|l|}{4} & \multicolumn{3}{|c|}{5} \\
\hline Strongly disagree & Disagree & Neutral & \multicolumn{2}{|l|}{ Agree } & \multicolumn{3}{|c|}{ Strongly agree } \\
\hline \multicolumn{8}{|c|}{ EVALUATION INDICATORS } \\
\hline \multirow{2}{*}{\multicolumn{3}{|c|}{$\begin{array}{l}\text { The objectives match the professional profile of the degree } \\
\text { The contents are associated with the different aspects of the } \\
\text { profession }\end{array}$}} & 1 & 2 & 3 & 4 & 5 \\
\hline & & & 1 & 2 & 3 & 4 & 5 \\
\hline \multicolumn{3}{|c|}{ The competences match the development of the profession } & 1 & 2 & 3 & 4 & 5 \\
\hline \multicolumn{3}{|c|}{$\begin{array}{l}\text { The teaching methodology matches the different learning } \\
\text { assignments }\end{array}$} & 1 & 2 & 3 & 4 & 5 \\
\hline \multicolumn{3}{|c|}{$\begin{array}{l}\text { The evaluation systems used match the different } \\
\text { assignments }\end{array}$} & 1 & 2 & 3 & 4 & 5 \\
\hline \multicolumn{3}{|c|}{$\begin{array}{l}\text { The bibliography and resources match the purposes of the } \\
\text { subject }\end{array}$} & 1 & 2 & 3 & 4 & 5 \\
\hline \multicolumn{3}{|c|}{$\begin{array}{l}\text { There are coordination systems between theoretical and } \\
\text { practical activities planned in the programme }\end{array}$} & 1 & 2 & 3 & 4 & 5 \\
\hline \multicolumn{3}{|c|}{$\begin{array}{l}\text { Proper organisation and presentation of the appropriate } \\
\text { materials (explanations, written materials, activities, etc.) }\end{array}$} & 1 & 2 & 3 & 4 & 5 \\
\hline
\end{tabular}




\begin{tabular}{|c|c|c|c|c|c|}
\hline \multicolumn{5}{|l|}{ EVALUATION INDICATORS } & \\
\hline $\begin{array}{l}\text { There is coherence between the objectives and the contents of } \\
\text { the subject and the activities performed }\end{array}$ & 1 & 3 & 4 & & 5 \\
\hline $\begin{array}{l}\text { A bibliography and/or relevant sources of information are } \\
\text { provided }\end{array}$ & 1 & 3 & 4 & 4 & 5 \\
\hline $\begin{array}{l}\text { There is a relationship between the different thematic units of } \\
\text { the subject }\end{array}$ & 1 & 3 & 4 & & 5 \\
\hline $\begin{array}{l}\text { Coordination among teachers to avoid overlaps and relates the } \\
\text { contents of the different subjects }\end{array}$ & 1 & 3 & 4 & 4 & 5 \\
\hline Monitoring of the students' learning process & 1 & 3 & 4 & & 5 \\
\hline Encouragement of student participation and motivation in class & 1 & 3 & 4 & 4 & 5 \\
\hline $\begin{array}{l}\text { Development of the students' capacity for synthesis and } \\
\text { reasoning }\end{array}$ & 1 & 3 & 4 & 4 & 5 \\
\hline $\begin{array}{l}\text { Use of methodologies to get students actively involved in } \\
\text { learning }\end{array}$ & 1 & 3 & & 4 & 5 \\
\hline $\begin{array}{l}\text { Organisation of the presentations to stress the most important } \\
\text { contents }\end{array}$ & 1 & 3 & & 4 & 5 \\
\hline $\begin{array}{l}\text { Explanation of examples in which the competences developed } \\
\text { by the subject are put into practice }\end{array}$ & 1 & 3 & & 4 & 5 \\
\hline $\begin{array}{l}\text { Promotion of the development of a reflective attitude in } \\
\text { students }\end{array}$ & 1 & 3 & & 4 & 5 \\
\hline $\begin{array}{l}\text { Proposals of activities to foster autonomous learning (search } \\
\text { for additional information, projects, research, etc.) }\end{array}$ & 1 & 3 & & 4 & 5 \\
\hline Use of clear, precise, rigorous language & 1 & 3 & 4 & 4 & 5 \\
\hline $\begin{array}{l}\text { Referral to students' opinions about issues related to the } \\
\text { development of teaching }\end{array}$ & 1 & 3 & & 4 & 5 \\
\hline The practices match the theoretical context of the subject & 1 & 3 & & 4 & 5 \\
\hline $\begin{array}{l}\text { The number of practices matches the development of the } \\
\text { cuhiert }\end{array}$ & 1 & 3 & & 4 & 5 \\
\hline Usefulness of practices to develop professional competences & 1 & 2 & 3 & 4 & 5 \\
\hline $\begin{array}{l}\text { Use of appropriate resources (black/whiteboard, } \\
\text { transparencies, audiovisual media, online support materials, } \\
\text { etc.) that facilitate learning }\end{array}$ & 1 & 2 & 3 & 4 & 5 \\
\hline $\begin{array}{l}\text { Development of teaching manuals to support the development } \\
\text { of the subject }\end{array}$ & 1 & 2 & 3 & 4 & 5 \\
\hline Design of workbooks to implement in the classroom & 1 & 2 & 3 & 4 & 5 \\
\hline $\begin{array}{l}\text { Information on the evaluation system at the beginning of the } \\
\text { class }\end{array}$ & 1 & 2 & 3 & 4 & 5 \\
\hline Information on the evaluation system during the class & 1 & 2 & 3 & 4 & 5 \\
\hline Information on the evaluation system at the end of the class & 1 & 2 & 3 & 4 & 5 \\
\hline $\begin{array}{l}\text { Evaluation is coherent with the objectives, contents, } \\
\text { methodology and activities of the class }\end{array}$ & 1 & 2 & 3 & 4 & 5 \\
\hline Variety of procedures to evaluate student learning & 1 & 2 & 3 & 4 & 5 \\
\hline Receptive attitude towards students & 1 & 2 & 3 & 4 & 5 \\
\hline Respect towards students & 1 & 2 & 3 & 4 & 5 \\
\hline Interest shown in the subject by the teacher & 1 & 2 & 3 & 4 & 5 \\
\hline Awareness of student difficulties & 1 & 2 & 3 & 4 & 5 \\
\hline $\begin{array}{l}\text { Encouragement for students to take an interest in their learning } \\
\text { process }\end{array}$ & 1 & 2 & 3 & 4 & 5 \\
\hline Creation of a participative work environment & 1 & 2 & 3 & 4 & 5 \\
\hline Promotion of fluid, spontaneous communication & 1 & 2 & 3 & 4 & 5 \\
\hline
\end{tabular}

\section{REFERENCES}

[1] Bassi M, Meghir C, Reynoso A. Education quality and teaching practices. National Bureau of Economic Research 2016. https://doi.org/10.3386/w22719

[2] Aleixo AM, Leal S, Azeiteiro UM. Conceptualization of sustainable higher education institutions, roles, barriers, and challenges for sustainability: An exploratory study in Portugal. Journal of Cleaner Production 2018; 172: 1664-73. https://doi.org/10.1016/j.jclepro.2016.11.010

[3] Arasteh $\mathrm{H}$. Education and Evolution of Higher Education: Historical Developments and Problems of Developing Countries 2005; 36.

[4] Saleem MA, Qureshi MI. Credentials and examination of the factors affecting the students' academic achievement in higher education (a case study of universities in public \& private sector at di khan). Gomal University Journal of Research 2011; 27(2): 74-80.

[5] Mousapour N. Concept of teaching and its basic questions. Development in Medical Education 2004; 48.
[6] Hoveida R, Molavi H. Improving the quality of education from viewpoint of faculty members of universities in Isfahan province: a comparison based on AQIP. Education in Medical Sciences 2004; 8(1): 132-141.

[7] García-Ruiz R, Guerra Liaño S, González Fernández N Álvarez Arregui E. Estudio exploratorio de las percepciones del profesorado universitario respecto a la gestión de la docencia 2010

https://doi.org/10.5944/educxx1.13.2.242

[8] López-Cámara AB, González-López I, de León-Huertas C. Exploratory factor analysis to construct a model of university teaching evaluation indicators/Un análisis factorial exploratorio para la construcción de un modelo de indicadores de evaluación docente universitaria. Cultura y Educación 2015; 27(2): 337-71. https://doi.org/10.1080/11356405.2015.1035546

[9] Hanushek. Piopiunik M. Wiederhold S. The Value of Smarter Teachers: International Evidence Teacher Cognitive Skills and Student Performance. Harvard Kennedy School79 JFK Street, Taubman304.Harvey, Lee, and James Williams. 2010. "Fifteen Years of Quality in Higher Education (Part two)."Quality in Higher Education 2013; 16(2): 81-113. 
[10] Espinosa LM. Curriculum and assessment considerations for young children from culturally linguistically, and economically diverse backgrounds. Psychology in the Schools 2005; 42: 837-853.

[11] Pekrun R. The control-value theory of achievement emotions: Assumptions, corollaries, and implications for educational research and practice. Educational Psychology Review 2006; 18(4): 315-41. https://doi.org/10.1007/s10648-006-9029-9

[12] Pekrun R, Goetz T, Frenzel AC, Barchfeld P, Perry RP. Measuring emotions in students' learning and performance: The Achievement Emotions Questionnaire (AEQ). Contemporary Educational Psychology 2011; 36(1): 36-48. https://doi.org/10.1016/j.cedpsych.2010.10.002

[13] Pekrun R, Stephens EJ. Academic emotions. In Harris KR, Graham S, Urdan T, Graham S, Royer JM, Zeidner M, (Eds.), APA handbooks in psychology. APA educational psychology handbook. Individual differences and cultural and contextual factors Washington, DC, US: American Psychological Association 2012; Vol. 2: pp. 3-31. http://dx.doi.org/10.1037/13274-001

[14] Villavicencio FT, Bernardo AB. Positive academic emotions moderate the relationship between self-regulation and academic achievement. British Journal of Educational Psychology 2013; 83(2): 329-40.

https://doi.org/10.1111/j.2044 8279.2012.02064.x

[15] Hernández-Amorós MJ, Urrea-Solano ME. Working with Emotions in the classroom: Future teachers' attitudes and education. Procedia-Social and Behavioral Sciences 2017; 237: 511-9.

https://doi.org/10.1016/j.sbspro.2017.02.100

[16] Saha D. Every hour, one student commits suicide in India. Hindustan Times 2017. Retrieved from https://www.hindustantimes.com/health-and-fitness/everyhour-one-student-commits-suicide-in-india/story7UFFhSs6h1HNgrNO60FZ2O.html

[17] Lee M, Larson R. The Korean 'examination hell': Long hours of studying, distress, and depression. Journal of Youth and Adolescence 2000; 29(2): 249-71.

https://doi.org/10.1023/A:1005160717081

[18] Fairbrother K, Warn J. Workplace dimensions, stress and job satisfaction. Journal of Managerial Psychology 2003; 18(1): 8-21.

https://doi.org/10.1108/02683940310459565

[19] Misra R, Castillo LG. Academic stress among college students: Comparison of American and international students. International Journal of Stress Management 2004; 11(2): 132.

https://doi.org/10.1037/1072-5245.11.2.132

[20] Hannibal KE, Bishop MD. Chronic stress, cortisol dysfunction, and pain: a psycho neuroendocrine rationale for stress management in pain rehabilitation. Physical Therapy 2014; 94(12): 1816-25.

https://doi.org/10.2522/ptj.20130597

[21] Landow M.W. Stress and Mental Health of College Students. Nova Science Publisher 2006.

[22] Gottfredson LS. Why g matters: The complexity of everyday Life. Intelligence 1997; 24(1): 79-132. https://doi.org/10.1016/S0160-2896(97)90014-3

[23] Deary IJ, Penke L, Johnson W. The neuroscience of human intelligence differences. Nature Reviews Neuroscience 2010; 11(3): 201.

https://doi.org/10.1038/nrn2793

[24] Hair JF, Ringle CM, Sarstedt M. PLS-SEM: Indeed a silver bullet. Journal of Marketing theory and Practice 2011; 19(2): 139-52. https://doi.org/10.2753/MTP1069-6679190202

[25] Colom R, Román FJ, Abad FJ, Shih PC, Privado J, Froufe M, Escorial S, Martínez K, Burgaleta M, Quiroga MA, Karama S.
Adaptive n-back training does not improve fluid intelligence at the construct level: Gains on individual tests suggest that training may enhance visuospatial processing. Intelligence 2013; 41(5): 712-27.

https://doi.org/10.1016/j.intell.2013.09.002

[26] Aronson J, Fried CB, Good C. Reducing the effects of stereotype threat on African American college students by shaping theories of intelligence. Journal of Experimental Social Psychology 2002; 38(2): 113-25. https://doi.org/10.1006/jesp.2001.1491

[27] Burnette JL, O'Boyle EH, VanEpps EM, Pollack JM, Finkel EJ. Mind-sets matter: A meta-analytic review of implicit theories and self-regulation. Psychological Bulletin 2013; 139(3): 655. https://doi.org/10.1037/a0029531

[28] Romero C, Master A, Paunesku D, Dweck CS, Gross JJ. Academic and emotional functioning in middle school: the role of implicit theories. Emotion 2014; 14(2): 227.

https://doi.org/10.1037/a0035490

[29] Blackwell LS, Trzesniewski KH, Dweck CS. Implicit theories of intelligence predict achievement across an adolescent transition: A longitudinal study and an intervention. Child Development 2007; 78(1): 246-63.

https://doi.org/10.1111/j.1467-8624.2007.00995.x

[30] Dweck CS. Mindset: The new psychology of success. Random House Digital, Inc.; 2008.

[31] Walton GM, Cohen GL. A brief social-belonging intervention improves academic and health outcomes of minority Students. Science 2011; 331(6023): 1447-51. https://doi.org/10.1126/science.1198364

[32] Yeager DS, Trzesniewski KH, Dweck CS. An implicit theories of personality intervention reduces adolescent aggression in response to victimization and exclusion. Child Development 2013; 84(3): 970-88. https://doi.org/10.1111/cdev.12003

[33] Busato VV, Prins FJ, Elshout JJ, Hamaker C. Intellectual Ability, learning style, personality, achievement motivationAnd academic success of psychology students in higher Education. Personality and Individual Differences 2000; 29(6): 1057-68.

https://doi.org/10.1016/S0191-8869(99)00253-6

[34] Kline RB. Principles and practice of structural equation modeling. Guilford Publications 2015.

[35] McQuitty S. Statistical power and structural equation models in business research. Journal of Business Research 2004; 57(2): 175-83. https://doi.org/10.1016/S0148-2963(01)00301-0

[36] Hair JF, Ringle CM, Sarstedt M. PLS-SEM: Indeed a silver bullet. Journal of Marketing theory and Practice 2011; 19(2): 139-52.

https://doi.org/10.2753/MTP1069-6679190202

[37] Peng DX, Lai F. Using partial least squares in operations management research: A practical guideline and summary of past research. Journal of Operations Management 2012; 30(6): 467-80.

https://doi.org/10.1016/j.jom.2012.06.002

[38] Camara Ana-Belen, Ignacio González-López and Carlota de León- Huertas: exploratory factor analysis to construct a model of university teaching evaluation indicators 2015/ Un análisis factorial exploratorio para la construcción de un modelo de indicadores de evaluación docente universitaria, Cultura y Educación 27(2): 337-371. https://doi.org/10.1080/11356405.2015.1035546

[39] Pekrun R, Goetz T, Titz W, Perry RP. Academic Emotions in Students" Self-Regulated Learning and Achievement: A Program of Qualitative and Quantitative Research. Educational Psychologist 2002; 37(2): 95-105. https://doi.org/10.1207/S15326985EP3702 4 
[40] García-Ros R, Pérez-González F, Tomás JM. Development and Validation of the Questionnaire of Academic Stress in Secondary Education: Structure, Reliability and Nomological Validity. International Journal of Environmental Research and Public Health 2018; 15(9): 2023. https://doi.org/10.3390/ijerph15092023

[41] Corey G, Corey MS, Muratori M. I Never Knew I Had a Choice. 2016 (11th ed.), 480. Cengage Learning. ISBN=1305945727

[42] Gefen D, Straub D. A practical guide to factorial validity using PLS-Graph: Tutorial and annotated example. Communications of the Association for Information Systems 2005; 16(1): 5. https://doi.org/10.17705/1CAIS. 01605

[43] Henseler J, Ringle CM, Sarstedt M. A new criterion for Assessing discriminant validity in variance-based structural Equation modeling. Journal of the Academy of Marketing Science 2015; 43(1): 115-35. https://doi.org/10.1007/s11747-014-0403-8

[44] Hair JF, Henseler J, Dijkstra TK, Sarstedt M. Common beliefs and reality about partial least squares: comments on Rönkkö and Evermann.

[45] Henseler J, Hubona G, Ray PA. Using PLS path modeling in new technology research: updated guidelines. Industrial Management \& Data Systems 2016; 116(1): 2-0. https://doi.org/10.1108/IMDS-09-2015-0382

[46] Chen JA, Tutwiler MS. Implicit theories of ability and selfefficacy. Zeitschrift für Psychologie 2017. https://doi.org/10.1027/2151-2604/a000289

[47] Stone M. Cross-validatory choice and assessment of statistical predictions. Journal of the Royal Statistical Society: Series B (Methodological) 1974; 36(2): 111-33. https://doi.org/10.1111/j.2517-6161.1974.tb00994.x

[48] Geisser $S$. The predictive sample reuse method with applications. Journal of the American Statistical Association 1975; 70(350): 320-8. https://doi.org/10.1080/01621459.1975.10479865

[49] Cohen J. Statistical power analysis for the behavioral sciences. Routledge 2013. https://doi.org/10.4324/9780203771587

[50] Memon Mumtaz Ali, Jun-Hwa Cheah, T. Ramaya, Hiram Tingd and Francis Chuahe: Mediation Analysis Issues and Recommendations. Journal of Applied Structural Equation Modeling 2018; 2(1): i-ix, elSSN: 2590-4221

[51] Aditomo A. Students' Response to Academic Setback:" Growth Mindset" as a Buffer against Demotivation.
International Journal of Educational Psychology 2015; 4(2): 198-222.

https://doi.org/10.17583/ijep.2015.1482

[52] Claro S, Loeb S. New evidence that students' beliefs about their brains drive learning. Evidence Speaks Reports 2017; 2(29).

[53] Bahadır-Yılmaz E: Academic and clinical stress, stress resources and ways of coping among Turkish first-year nursing students in their first clinical practice. 2016 kontakt 18 (2016 e148) e145-e151

[54] Costa A, Faria L. Implicit theories of intelligence and academic achievement: A meta-analytic review. Frontiers in Psychology 2018; 9. https://doi.org/10.3389/fpsyg.2018.00829

[55] Claro, S., Paunesku, D., \& Dweck, C.S. (2016). Growth mindset tempers the effects of poverty on academic achievement. Proceedings of the National Academy of Sciences of the United States of America, $11331,8664-8$. https://doi.org/10.1073/pnas.1608207113

[56] Beck AT, Steer RA, Brown GK. Manual for the beck depression inventory-II. San Antonio, TX: Psychological Corporation 1996; 1: 82.

https://doi.org/10.1037/t00742-000

[57] Ruzek E, Hafen C, Allen J, Gregory A, Mikami A, Pianta CR. How teacher emotional support motivates students: The mediating roles of perceived peer relatedness, autonomy support, and competence. Learn Instr 2016; 42: 95-103. https://doi.org/10.1016/j.learninstruc.2016.01.004

[58] Reyes MR, Brackett MA, Rivers SE, White M, Salovey P. Classroom emotional climate, student engagement, and academic achievement. Journal of Educational Psychology 2009; 104(3): 700-712. http://dx.doi.org/10.1037/a0027268

[59] Rimm-Kaufman SE, Fan X, Chiu Y-J, You W. The contribution of the Responsive Classroom Approach on children's academic achievement: Results from a three year longitudinal study. Journal of School Psychology 2009; 45(4): 401-421.

http://dx.doi.org/10.1016/j.jsp.2006.10.003

[60] Pianta RC, Hamre BK. Conceptualization, measurement, and improvement of classroom processes: Standardized observation can leverage capacity. Educational Researcher 2009; 38(2): 109-119. https://doi.org/10.3102/0013189X09332374

[61] Pekrun r: Emotions and Learning. International Academy of Education, more information (2014), see the IAE's website at: http://www.iaoed.org.

Received on 13-06-2019

Accepted on 24-06-2019

Published on 06-08-2019

\section{DOI: https://doi.org/10.6000/2292-2598.2019.07.03.9}

(C) 2019 Nazari and Far; Licensee Lifescience Global.

This is an open access article licensed under the terms of the Creative Commons Attribution Non-Commercial License (http://creativecommons.org/licenses/by-nc/3.0/) which permits unrestricted, non-commercial use, distribution and reproduction in any medium, provided the work is properly cited. 